\title{
Management of Application Character Education at Sekolah Dasar Kemala Bhayangkari, Balikpapan
}

\author{
Akhmad \\ Biology Education Program \\ Teacher Training and Education Faculty of \\ Mulawarman University \\ Samarinda, Indonesia \\ akhmad_63@yahoo.com
}

\author{
PM. Labulan \\ Mathematics Education Program \\ Teacher Training and Education Faculty of \\ Mulawarman University \\ Samarinda, Indonesia \\ pm_labulan@yahoo.co.id
}

\begin{abstract}
This study aimed to examine and describe the management of application character education at Elementary School namely Sekolah Dasar (SD) Kemala Bhayangkari, Balikpapan city, East Kalimantan, Indoneisa. We conducted guided interview with school principal followed by giving him the questionnaire. The data was analyzed using qualitative technique that consist several steps; data collection, data reduction, data display, and conclusion. The present study shows that character education were applied at SD Kemala Bhayangkari in planning stage, implementing stage, and evaluating stages. The application of character education was supported by behavioral culture of School's principal reflected in routine school activities. Our study revealed that SD Kemala Bhayangkari have applied various values of character education in very good category. In conclusion, our study demonstrated that character education should be developed in three stages, which are planning stages, implementing stages, and evaluating stages. Furthermore, Principal's culture behavior is important in realizing those character educations in school.
\end{abstract}

Keywords: management, principal's culture behavior, application character education

\section{INTRODUCTION}

Character education in teaching and learning process at school is very important in order to have a good quality of human resources. Therefor proper learning management is needed to achieve the educational goals which are mandated in the National Education System Act. According to the National Commitment, character education should be implemented integrated in learning process such as Science's learning.

The character in Science's learning process is really needed in order to have a good personality, resulted student not easily believe in issues that are not clearly proven. Sekolah Dasar (SD) Kemala Bhayangkari Balikpapan is one of referral schools that had a character education. This school is considered capable of carrying out character education in the learning process, starting with the stages of planning, implementing, and evaluating.

However, there is lack information about management of application character education in Science's learning process and also the behavioral culture of School's Principle. Thus, further research is needed to examine and describe the management of application character education at SD Kemala Bhayangkari through planning, implementing, and evaluating stages and also the behavioral culture of School's principle that applying the character education.

\section{METHOD}

This study is the descriptive research with qualitative approach. The study was carried out at SD Kemala Bhayangkari in Balikpapan city, East Kalimantan Province, Indonesia for a week. In addition, SD Kemala Bhayangkari also well known as Adwiyata in the field of clean and healthy school environment. Data were collected by documentation, guided interviews and questionnaires. Data analysis was carried out with three stages, which are data collection, data reduction, and data display and conclusion drawing/verification. Validity test for qualitative research used some test; credibility test (internal validity), transferability test (external validity), dependability test (reliability), and confirmability (objectivity).

\section{RESUlT AND DisCUSSION}

\section{A. General Description}

SD Kemala Bhayangkari founded by Kemala Bhayangkari Foundation in 1959, located at Jalan Jendral Sudirman Kelandasan Ulu Village, Balikpapan, East Kalimantan Province, Indonesia. SD Kemala Bhayangkari has 442 students (211 male and 231 female) in the academic year of 2018/2019. Furthermore, there were 31 teaching staff and 23 permanent foundation teachers and 23 nonpermanent foundation and 8 permanent foundation employees and non-permanent foundation employees. SD Kemala Bhayangkari leaded by Baharuddin M.Pd. He always committed to realizing the vision and mission of the school and continues to make improvements of Nation Character Program that launched by the Central Government.

\section{B. Application of character education in learning process}

We investigated the application of character education in planning, implementing, and evaluating stage during science learning process at SD Kemala Bhayangkari. We found that character values that shown in table 1 . was applied in every stages of science learning management (Table 2). We found that in planning aspect, science teacher developed value of character education into the curriculum like syllabus or lesson plans that used in learning process. Application of character values which developed in lesson plan is reflected in the learning steps compiled by teacher by lectures 
methods, discussion, questions and answers, and also assignments.

In implementation aspect, character values was applied in 3 main activities which are preliminary, core, and closing activities. Application of preliminary activities in the class is praying followed by greeting teacher to student before start the lessons. The core activity by discussion methods was a strategy used by teacher to apply the values of discipline, hard work, diligent, communicative, and creative. To develop the value of respect and responsibility, communicative and confident, teacher will give a reward or praise for the work that has been done and find a solution from a problem. The closing activities do by saying greetings and praying at the end of the lesson. This is a strategy to implementing a responsible attitude towards God Almighty.

Last, in evaluating aspect, teacher conducted an evaluation in two different ways, which are daily test and assignment. Daily test conducted by the teacher aim to evaluate students' understanding and mastery of the given lesson that based on basic competencies namely kompetensi dasar (KD). The character values that embedded are integrity, confidence and independence. While the evaluation of assignment both individually and group was done by checking one by one the work of students. The embedded character value is the value of responsibility towards the given task.

TABLE I.

CHARACTER VALUES APPLIED IN LEARNING PROCESS

\begin{tabular}{|c|c|c|}
\hline \multicolumn{3}{|c|}{18 Values in Character Education } \\
\hline Religious & Honest & Tolerance \\
\hline Discipline & Hard work & Creative \\
\hline Independent & Democratic & Curiosity \\
\hline Nationality spirit & Love the nation & Reward achievement \\
\hline Friendly / Communicative & Love peace & Like to read \\
\hline Environmental care & Social care & Responsible \\
\hline
\end{tabular}

TABLE II. APPLICATION OF CHARACTER EDUCATION IN SD KEMALA BHAYANGKARI

\begin{tabular}{|c|c|c|c|}
\hline No & Aspect & Indicator & Developed value \\
\hline \multirow[t]{2}{*}{1} & \multirow{2}{*}{$\begin{array}{l}\text { Management of the } \\
\text { application of } \\
\text { character education } \\
\text { in Science Learning } \\
\text { Planning in SD } \\
\text { Kemala } \\
\text { Bhayangkari, } \\
\text { Balikpapan }\end{array}$} & Syllabus & $\begin{array}{l}\text { Religious, nationalist, } \\
\text { independent, mutual } \\
\text { cooperation, integrity }\end{array}$ \\
\hline & & Lesson plan & $\begin{array}{l}18 \text { values from the main } \\
\text { character value }\end{array}$ \\
\hline \multirow[t]{3}{*}{2} & \multirow{3}{*}{$\begin{array}{l}\text { Management of the } \\
\text { application of } \\
\text { character education } \\
\text { in the } \\
\text { Implementation of } \\
\text { Science Learning in } \\
\text { SD Kemala } \\
\text { Bhayangkari } \\
\text { Balikpapan }\end{array}$} & $\begin{array}{l}\text { Preliminary } \\
\text { activities }\end{array}$ & $\begin{array}{l}\text { Religious, responsibility, } \\
\text { nationalist, confident }\end{array}$ \\
\hline & & $\begin{array}{l}\text { Core } \\
\text { activities }\end{array}$ & $\begin{array}{l}\text { Independent, } \\
\text { responsibility, discipline, } \\
\text { confidence }\end{array}$ \\
\hline & & $\begin{array}{l}\text { Closing } \\
\text { activities }\end{array}$ & $\begin{array}{l}\text { Religious, integrity and } \\
\text { responsibility }\end{array}$ \\
\hline \multirow[t]{2}{*}{3} & \multirow{2}{*}{$\begin{array}{l}\text { Management of the } \\
\text { application } \\
\text { character education } \\
\text { in the Science } \\
\text { Learning Evaluation } \\
\text { at SD Kemala } \\
\text { Bhayangkari } \\
\text { Balikpapan }\end{array}$} & Daily test & $\begin{array}{l}\text { Independent, confident, } \\
\text { integrity }\end{array}$ \\
\hline & & Assignment & $\begin{array}{l}\text { Responsibility, discipline, } \\
\text { independent }\end{array}$ \\
\hline
\end{tabular}

TABLE III. APPLICATION OF CHARACTER EDUCATION IN SD KEMALA BHAYANGKARI

\begin{tabular}{|c|c|c|}
\hline Aspect & Indicator & Activities \\
\hline \multirow{7}{*}{$\begin{array}{l}\text { Management of } \\
\text { the application of } \\
\text { character } \\
\text { education in } \\
\text { Science Learning } \\
\text { Planning in SD } \\
\text { Kemala } \\
\text { Bhayangkari, } \\
\text { Balikpapan }\end{array}$} & $\begin{array}{l}\text { Efforts to } \\
\text { always be } \\
\text { disciplined }\end{array}$ & $\begin{array}{l}\text { 1. Come earlier than students } \\
\text { 2. Pick up students at the gate } \\
\text { 3. Picket } \\
\text { 4. The rules are enforced } \\
\text { 5. Do habituation }\end{array}$ \\
\hline & $\begin{array}{l}\text { Improve } \\
\text { technical } \\
\text { ability }\end{array}$ & $\begin{array}{l}\text { 1. Deliberation } \\
\text { 2. Training } \\
\text { 3. Seminar } \\
\text { 4. Cooperation in MKKS } \\
\text { Personal development (PKB) }\end{array}$ \\
\hline & $\begin{array}{l}\text { Running the } \\
\text { school } \\
\text { organizational } \\
\text { structure }\end{array}$ & $\begin{array}{l}\text { 1. Make a description of the } \\
\text { activities of each } \\
\text { organization } \\
\text { 2. Cooperation of all } \\
\text { components } \\
\text { 3. Creating a working group } \\
\text { 4. Make and deliver the results } \\
\text { of activities ranging from } \\
\text { planning, implementation, } \\
\text { evaluation, and follow-up }\end{array}$ \\
\hline & $\begin{array}{l}\text { Honest in } \\
\text { carrying out } \\
\text { the mandate }\end{array}$ & $\begin{array}{l}\text { Carried out in accordance with } \\
\text { their respective duties } \\
\text { entrusted with full } \\
\text { responsibility }\end{array}$ \\
\hline & $\begin{array}{l}\text { Complete } \\
\text { administrative } \\
\text { document }\end{array}$ & $\begin{array}{l}\text { Making teaching tools every } \\
\text { semester (Kaldik, Prota, } \\
\text { Promed, RME, KKM, } \\
\text { Evaluation, Analysis, Remedial } \\
\text { Program, styling program) }\end{array}$ \\
\hline & $\begin{array}{l}\text { Following } \\
\text { education and } \\
\text { training }\end{array}$ & $\begin{array}{l}\text { Always attend training and } \\
\text { guidance both inside and } \\
\text { outside of school }\end{array}$ \\
\hline & $\begin{array}{l}\text { Providing } \\
\text { excellent } \\
\text { service }\end{array}$ & $\begin{array}{l}\text { There are special services and } \\
\text { general services provided to } \\
\text { students, programmed and not } \\
\text { programmed }\end{array}$ \\
\hline
\end{tabular}

\section{Principal behavior culture}

We investigated the principal's culture behavior in applying character education at SD Kemala Bhayangkari. Our result showed that principal have behavioral culture that support the application of character education shown in table 3 .

Culture of Principal's behavior consists of: (1) Strive to discipline and build a shared commitment to uphold the school rules, and make a habit to arrive earlier to welcome students, (2) increase technical abilities through training, seminars and working groups of school principals namely musyawarah kerja kepala sekolah (MKKS), (3) running the school organizational structure by making a description in the distribution of tasks and delivering the results of activities ranging from planning, implementation, evaluation, and follow-up, (4) doing the mandate and task with honesty and full responsibility, (5) join the education and training in referral schools to form principals' strengthening and school management strengthening both within the school environment and outside of school, (6) complete the administrative document by make a teaching tools in every stages (education calendar, annual and semester programs, effective week plan, minimum completeness criteria, evaluation, analysis, remedial programs, and styling programs), (7) provide the responsive service both special and general service to students, parents and other educational elements. 
Based on the description above, it emphasized that implementing of character education in school, the leadership of a school principal plays a very important role and influences the personality of students, teachers and employees both directly and indirectly. Policies of school principal are very important because it will be transformed and reflected to the teachers and employees and then continue to the students. Building the character is building the habits, and building the habits is building the character.

\section{Implementation of Character Education in SD Kemala Bhayangkari}

Implementation of character education in SD Kemala Bhayangkari viewed from some aspects which are: (1) Planning that includes vision and mission of the school, objectives to be achieved and curriculum structure shows excellent categories, (2) implementation of curriculum content and learning process in implementing 18 character values show excellent categories, (3) evaluation or assessment of teacher in implementing character education show excellent categories, and (4) supporting facilities for develop character values also shows excellent categories.

Based on the discussion above, it shows that character education is an efforts that designed and carried out systematically to help students understand the values of human behavior related to God Almighty, self, fellow human beings, and the environment.

In summary, our study revealed the implementation of character education in learning process management. The character values that applied and implemented in learning process related to Principal's behavioral culture. Furthermore, our study might be used to motivate the educational institutions as well as teachers to implement character education in learning process.

\section{CONCLUSION}

In conclusion, application of character education in science learning process at SD Kemala Bhayangkari was applied in three aspect of management, which is planning, implementing and evaluating. Furthermore, the principal's behavioral culture was very important in implementing character education. In addition, application of character education in SD Kemala Bhayangkari showed excellent categories.

\section{ACKNOWLEDGMENT}

The author would like to acknowledge the Kemala Bhayangkari Elementary School Balikpapan that supports this study. We thank to Ms. Putri Anggreini for her valuable technical assistance.

\section{REFERENCES}

[1] Z. Aqib, and Sujak, Guidance and application of character education, Panduan dan aplikasi pendidikan karakter, Bandung: Yrama Widya, 2011.

[2] M. Asyari, Implementation of science technology society in science learning at elementary school, Penerapan sains teknologi masyarakat dalam. pembelajaran sains di SD, Jakarta: Depdiknas Dirjen Dikti Direktorat Ketenagaan, 2006.

[3] P. Bundu, Assesment of science process skill and attitude in science learning at elementary school, Penilaian keterampilan proses dan sikap ilmiah dalam pembelajaran sains sekolah dasar, Jakarta: Depdiknas, 2006

[4] B. Bungin, Qualitative research methodology, Metodologi penelitian kualitatif, Jakarta: PT Raja Grafindo, 2004.

[5] Depdiknas, Guidance development of integrated science learning, Panduan pengembangan pembelajaran IPA terpadu, Jakarta: Puskur, Balitbang Depdiknas, 2007.

[6] H. Gunawan, Character education, concept and implementation, Pendidikan karakter, konsep dan implementasi, Bandung: Alfabeta, 2012.

[7] D. Kesuma, C. Triatna, and J. Permana, Character education, Pendidikan karakter, Bandung: Remaja Rosdakarya, 2011.

[8] M.B. Miles, and A.M. Huberman, Qualitative data analysis, Analisis data kualitatif, Jakarta: Universitas Indonesia, 2009.

[9] Mulyasa, Management of character education, Manajemen pendidikan karakter, Jakarta: PT. Bumi Aksara, 2012.

[10] M. Samani and Hariyanto, Concept and model of character education, Konsep dan model pendidikan karakter, Semarang: Rosda, 2011.

[11] U. Munandar, Development of talented children creativity, Pengembangan kreativitas anak berbakat, Rineka Cipta: Jakarta, 2009.

[12] M. Muslich, Character education: answer crisis challenge of multidimensional, Pendidikan karakter: menjawab tantangan krisis multidimensional, Jakarta: Bumi Aksara, 2011.

[13] M. Samani and Hariyanto, Character education, Pendidikan karakter, Bandung: PT Remaja Rosdakarya, 2012.

[14] Sardiman, Interaction and motivation teaching and learning, Interaksi dan motivasi belajar mengajar, Jakarta: PT. Raja Grafindo Persada, 2012.

[15] Sugiyono, Education research method, Metode penelitian pendidikan, Bandung: Alfabeta, 2013.

[16] Zubaedi, Design of character education, concept and application in education institution, Desain Pendidikan Karakter, Konsepsi dan Aplikasi dalam Lembaga Pendidikan, Jakarta: Kencana Prenada Media Group, 2011.

[17] Anonym, National education system, Sistem Pendidikan Nasional, Undang-Undang Nomor 20 Tahun 2003, Jakarta: Departemen Pendidikan Nasional RI, 2003. 